\title{
Diagnostic and prognostic value of DNA image cytometry in myelodysplasia
}

\author{
W AUFFERMANN, * INGRID FOHLMEISTER, $†$ A BÖCKING* \\ From the Departments of Pathology of the *Technical University of Aachen and the †University of Cologne, \\ Federal Republic of Germany
}

SUMMARY The DNA content of erythropoietic cells from 10 patients with refractory anaemia (RA) with megaloblastic changes, who subsequently developed acute non-lymphoblastic leukaemia (ANL), and from seven patients with megaloblastic marrow aspirates due to pernicious anaemia were compared by DNA image cytometry. The DNA distribution, the rate of aneuploid cells exceeding $5 \mathrm{c}$ (5cER), and the square deviation index of DNA values from the normal 2c-peak (2cDI) were recorded. Both variables were of diagnostic and prognostic importance for epithelial tumours, malignant lymphomas, and dysplastic lesions. A rate of 5cER $>0$ was found in eight of 10 myelodysplastic, but in none of seven control cases. Hypodiploidy was equally pronounced in both groups of patients. The $5 \mathrm{cE}$ had the highest discriminative value of all variables calculated. The $2 \mathrm{cDI}$ was not significantly different in either group. In pernicious anaemia the $2 \mathrm{cDI}$ depended mainly on the percentage of S cells, reflecting the defect of DNA synthesis. In RA with megaloblastosis the 2cDI correlated with the percentage of $G_{2}$ cells, reflecting $G_{2}$ arrest. In the myelodysplastic group the $2 \mathrm{cDI}$ correlated positively with the length of time until ANL developed, indicating the prognostic relevance of 2cDI. Our findings show that in megaloblastic anaemia DNA image cytometry can distinguish myelodysplasia from pernicious anaemia and that it also provides prognostic information.

Myelodysplastic syndromes (MDS) comprise a range of conditions which vary in their degree of risk of transformation to "overt" acute non-lymphoblastic leukaemia (ANL).' In clinical practice diagnosis and classification of MDS are mainly based on a wide range of morphological features, ${ }^{2-6}$ but the predictive value of morphological features for risk of transformation to ANL is controversial. Moreover, discrimination between MDS and reactive changes is not always possible.' While it has been shown with cytogenetic methods that MDS are usually clonal, ${ }^{7-10}$ such methods fail to detect small clones of low mitotic activity.

Another way to define MDS has been tried using DNA flow cytometry, ${ }^{11-14}$ which detects an abnormal DNA content even in slowly proliferating or resting cell clones, and permits the study of the cytokinetic characteristics of cell populations. DNA image cytometry combines the advantages of flow cytometry with the ability to select individual cells and is regarded as capable of detecting the "rare event" aneuploid cell. ${ }^{15}$ To test the value of this method in MDS we applied it to clinical circumstances where problems in discriminating true MDS from secondary

Accepted for publication 4 February 1988 changes can arise. We chose to examine megaloblastic anaemia, which may either show a certain degree of responsiveness to B12 or folate substitution despite being due to MDS, or on the other hand, may be refractory to treatment in secondary cases-for example, in alcoholism. ${ }^{1}$

We compared the cytometric data of erythropoietic cells from 10 patients with megaloblastic anaemia who subsequently developed ANL with those of seven patients who exhibited a characteristic B12 response and had pernicious anaemia. For this comparison, we applied a previously described algorithm, ${ }^{16}$ the diagnostic and prognostic importance of which has been shown for solid tumours, ${ }^{17-23}$ malignant lymphomas, ${ }^{24} 25$ and dysplastic epithelial lesions..$^{20-22}$

\section{Material and methods}

Bone marrow smears of 10 patients with the initial diagnosis of megaloblastic anaemia were selected from haematological material from the Institute of Pathology of the University of Cologne. Subsequent development of ANL was documented in all 10 patients. According to the FAB criteria, nine cases were classified as refractory anaemia (RA), four (cases 8-11) without, and five (cases 12-16) with pan- 
cytopenia. One patient (case 17) showed refractory anaemia with slight excess of blasts (RAEB). Five patients (cases 8-11 and 17) exhibited slight to moderate and three (cases 12-14) severe nuclear abnormalities of erythropoietic cells, such as nuclear budding and fragmentation. Four patients (cases 9, $10,15,17)$ also showed micromegakaryocytes. In three cases (cases 15-17) a partial myeloperoxidase deficiency was also seen.

ANL developed one to 11 months after the initial cytological diagnosis. Leukaemia was classified as M1 in four cases, as M4 in four cases, as M5a in one, and as M6 in one (table). Seven cases with B12 responsive pernicious anaemia served as controls. Four of them (cases 4-7) exhibited slight to moderate nuclear abnormalities of erythropoietic cells. All specimens were analysed by DNA image cytometry without knowledge of the final diagnosis.

\section{DNA IMAGE CYTOMETRY}

DNA image cytometry was performed with an automatic microscope using a computer controlled television image analysis system (TAS plus, Leitz, West Germany), which includes a video memory for automatic relocation of cells as described previously. ${ }^{26}$ After photographical mapping of 150 erythropoietic cells in bone marrow smears stained by the Pappenheim method the slides were subjected to hydrolysis (4N hydrochloric acid at $28^{\circ} \mathrm{C}$ for 45 minutes) and then stained with Schiff's reagent according to the Feulgen method. Erythropoietic nuclei were relocated and marked manually on the screen using a light pen. The integrated optical density and the total area of a mask adapted individually to the shape and size of each individual nucleus were measured. Masks of touching nuclei were automatically separated before measurement. The diploid (2c) standard for erythropoietic cells was defined as the mean of 20 granulocytes, determined in identical specimens. DNA measurements of 100 to 150 erythropoietic nuclei were processed by the computer using the following algorithm.

\section{ALGORITHM}

The algorithm used in this study has been reported previously. ${ }^{1617}$ This algorithm describes the prospective development of cell populations by computing two variables from the DNA histogram: the 5cER and the $2 \mathrm{cDI}$. The $5 \mathrm{cE}$ represents the percentage of cells with a DNA content of more than $5 \mathrm{c}$ but less than $8 \mathrm{c}$ or $16 c \pm 12.5 \%$ and is taken as an index for aneuploidy. It can also be taken as a hyperdiploidy index. $2 \mathrm{cDI}$ represents the square deviation from the $2 \mathrm{c}$ value and is increased by all influences which deviate the cellular DNA content from the normal $2 \mathrm{c}$ value: increase of the fraction of proliferating cells, shortening of the $G_{1}$ phase, prolongation of the $S$ or $G_{2}$ phase, hypodiploidy and hyperdiploidy.

The algorithm is only applicable to tissues not previously treated with radiation or cytostatic agents and only to cells without cytologically detectable virus infection. ${ }^{16}{ }^{17}$ Furthermore, in all patients the fraction of cells with $2 n, 4 n, 2 n-4 n$ and $(2 n-4 n) / 4 n$ DNA content was calculated according to Silvestrini et al and Riccardi et al..$^{27}$ Cells were taken as $2 \mathrm{n}$ or $4 \mathrm{n}$, respectively, when their DNA content was within an interval of $\pm 12.5 \%$ of the respective value. The percentage of hypodiploid cells was determined in each case.

The significance of differences was calculated using the Wilcoxon rank test (continuous variables). For comparison of frequency distributions an exact contingency table test (dichotomous or categorised variables) was applied. Correlations between the various categories of values were evaluated using the Spearman rank correlation coefficient.

Table Clinical, cytological, and DNA-cytometric findings in 10 patients with RA and megaloblastosis, and in seven controls with pernicious anaemia

\begin{tabular}{|c|c|c|c|c|c|c|c|c|c|}
\hline $\begin{array}{l}\text { Case } \\
\text { No }\end{array}$ & $\begin{array}{l}\text { Clinicomorphological } \\
\text { diagnosis }\end{array}$ & $5 c E R$ & $2 c D I$ & $2 n-4 n \%$ & $4 n \%$ & $(2 n-4 n) / 4 n$ & Hypodiploidy & $\begin{array}{l}\text { Nuclear } \\
\text { abnormalities }\end{array}$ & Follow up \\
\hline $\begin{array}{r}1 \\
2 \\
3 \\
4 \\
5 \\
6 \\
7 \\
8 \\
9 \\
10 \\
11 \\
12 \\
13 \\
14 \\
15 \\
16 \\
17\end{array}$ & $\begin{array}{l}\text { Pernicious anaemia } \\
\text { Pernicious anaemia } \\
\text { Pernicious anaemia } \\
\text { Pernicious anaemia } \\
\text { Pernicious anaemia } \\
\text { Pernicious anaemia } \\
\text { Pernicious anaemia } \\
\text { RA } \\
\text { RA } \\
\text { RA } \\
\text { RA } \\
\text { RA with pancytopenia } \\
\text { RA with pancytopenia } \\
\text { RA with pancytopenia } \\
\text { RA with pancytopenia } \\
\text { RA with pancytopenia } \\
\text { RAEB }\end{array}$ & $\begin{array}{l}0 \\
0 \\
0 \\
0 \\
0 \\
0 \\
0 \\
0 \cdot 93 \\
1 \cdot 67 \\
0 \\
2 \\
4 \cdot 4 \\
4 \cdot 3 \\
2 \cdot 67 \\
0 \\
1 \\
2 \cdot 15\end{array}$ & $\begin{array}{l}1 \cdot 70 \\
0.64 \\
0.96 \\
2 \cdot 12 \\
1 \cdot 74 \\
1.82 \\
1.09 \\
1.08 \\
0.82 \\
1.59 \\
1.72 \\
7.79 \\
1.58 \\
3.07 \\
0.76 \\
0.63 \\
2.63\end{array}$ & $\begin{array}{l}18 \cdot 0 \\
51 \cdot 0 \\
13 \cdot 0 \\
4 \cdot 0 \\
1 \cdot 0 \\
14 \cdot 5 \\
29 \\
14 \\
15 \cdot 5 \\
19 \\
10 \\
15 \cdot 5 \\
19 \cdot 0 \\
20 \\
35 \cdot 5 \\
14 \cdot 7 \\
20\end{array}$ & $\begin{array}{l}12 \\
6 \\
13 \\
15 \\
17 \\
17 \cdot 5 \\
17 \\
7 \\
4 \cdot 5 \\
18 \\
2 \\
17 \cdot 5 \\
8 \\
15 \\
8 \cdot 5 \\
4 \\
14\end{array}$ & $\begin{array}{l}1 \cdot 50 \\
8 \cdot 5 \\
1 \\
0 \cdot 27 \\
0 \cdot 06 \\
0 \cdot 82 \\
1 \cdot 7 \\
2 \\
3 \cdot 4 \\
1 \cdot 1 \\
6 \\
0 \cdot 9 \\
2 \cdot 4 \\
1 \cdot 3 \\
4 \cdot 2 \\
3 \cdot 7 \\
1 \cdot 4\end{array}$ & $\begin{array}{r}0 \\
0 \\
30 \\
2 \\
5 \\
1 \\
12 \\
18 \\
36 \\
4 \\
6 \\
5 \\
32 \\
7 \\
5 \\
56 \\
0\end{array}$ & $\begin{array}{l}0 \\
0 \\
0 \\
+ \\
+ \\
+ \\
+ \\
+ \\
+ \\
+ \\
+ \\
++ \\
++ \\
++ \\
0 \\
0 \\
+\end{array}$ & $\begin{array}{l}\text { Response to B-12 } \\
\text { Response to B-12 } \\
\text { Response to B-12 } \\
\text { Response to B-12 } \\
\text { Response to B-12 } \\
\text { Response to B-12 } \\
\text { Response to B-12 } \\
\text { M1 after } 8 \text { months } \\
\text { M4 after } 1 \text { month } \\
\text { M1 after } 5 \text { months } \\
\text { M5a after } 8 \text { months } \\
\text { M1 after } 11 \text { months } \\
\text { M4 after } 6 \text { months } \\
\text { M6 after } 2 \text { months } \\
\text { M4 after } 1 \text { month } \\
\text { M1 after } 2 \cdot 5 \text { months } \\
\text { M4 after } 7 \text { months }\end{array}$ \\
\hline
\end{tabular}




\section{Results}

Results of DNA image cytometry and morphological evaluation are given in the table. 5cER was greater than 0 in eight of 10 cases of MDS and in none of seven control cases. The difference was significant $(p<$ 0.0023). 5cER is therefore a possible diagnostic indicator of hyperdiploid aneuploidy, which was found only in MDS. Hypodiploidy, on the other hand, which is not included in this index, was also present in pernicious anaemia (cases 3 and 7). Hypodiploidy did not discriminate MDS from control cases. A diagnostic value of other variables calculated from the DNA histograms, as $2 \mathrm{cDI}, 4 n \%,(2 n-4 n \%),(2 n-4 n) \%+$ $4 n \%$, and $(2 n-4 n) / 4 n$ was not evident. There was also no correlation of morphological nuclear abnormalities, either to the final diagnosis $(p<0.5)$ or to 5cER ( $<<0.5)$.

The $2 \mathrm{cDI}$, as well as the percentages of $(2 n-4 n)$ cells and $4 \mathrm{n}$ cells, were highly variable in pernicious anaemia and in MDS. In the group with pernicious anaemia $2 \mathrm{cDI}$ was negatively correlated with $(2 n-4 n)$ / $4 n(p<0.01)$. $(2 n-4 n) / 4 n$ showed a positive correlation with $(2 n-4 n)(p<0.001)$ and $(2 n-4 n) / 4 n(p<$ 0.005 ). There was no correlation between $2 \mathrm{cDI}$ and the percentage of hypodiploid cells. In MDS $2 \mathrm{cDI}$ was negatively correlated with $(2 n-4 n) / 4 n(p<0.001)$. In MDS 2cDI was positively $(p<0.05)$, and $(2 n-4 n) / 4 n$ negatively $(p<0.005)$ correlated with $4 n \% .2 \mathrm{cDI}$ was also positively correlated with 5cER $(p<0.001)$ and negatively with hypodiploidy ( $p<0.05$ ).

To find out whether there was a prognostic implication to be derived from any DNA variable, data were correlated with the time interval between initial cytological diagnosis and the date of transformation to ANL (transformation time). As a result, $2 \mathrm{cDI}$ was the only variable that correlated with transformation time $(p<0.05)$; all other DNA variables, morphological nuclear abnormalities, as well as FAB criteria showed no correlation with prognosis. Representative histograms of two cases of MDS with different transformation time intervals are shown in the figure.

\section{Discussion}

Among the myelodysplastic syndromes the risk of developing ANL is particularly indeterminate for those classified as RA or acquired idiopathic sideroblastic anaemia (AISA). This is partly due to the difficulty in discriminating them from secondary changes. Since MDS has been shown to be of a clonal nature, ${ }^{7-10}$ an early indicator of developing clonality would be helpful. Aneuploidy of the pathological clone may be used as a marker, but small aneuploid clones of low mitotic activity with minor chromosomal aberrations may escape detection by cytogenetic methods or DNA flow cytometry. ${ }^{1329}$

In our study we used DNA image cytometry to discriminate RA with megaloblastosis from pernicious anaemia. Only erythropoietic cells were measured and only values exceeding $5 \mathrm{c}$ were accepted as abnormal $(5 \mathrm{cER}>0)$. Using this algorithm, eight of $10 \mathrm{RA}$ cases with megaloblastosis and subsequent development of ANL exhibited an abnormal DNA distribution pattern, which was not seen in any of the seven control cases with pernicious anaemia.

Compared with $40-50 \%$ of MDS cases with cytogenetic abnormalities, ${ }^{30}$ the sensitivity of this method in discriminating clonal disease from deficiency states seems to be high. This is due to the fact that even small numbers of aneuploid cells are detected, irrespective of their mitotic activity. It might

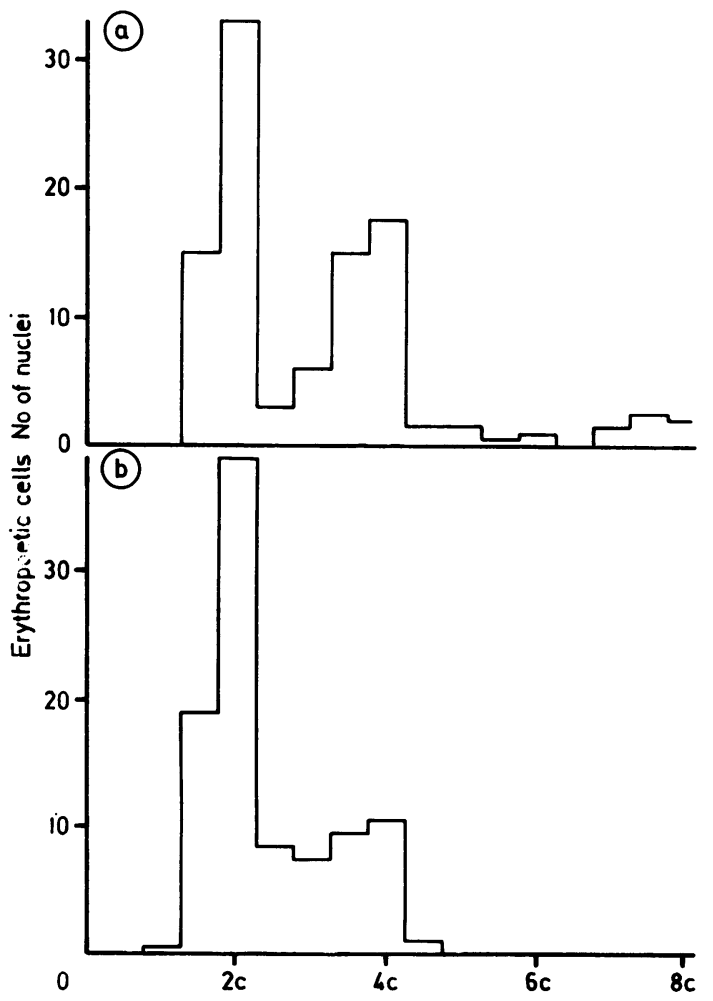

Figure Typical DNA histograms of erythropoietic cells in $R A$ with megaloblastosis. (a) Case 12: slight hyperdiploid aneuploidy $(5 c E R=4.4)$. Strongly increased variation around the normal $2 c$ value $(2 c D I=7 \cdot 79)$, partly due to $\mathrm{G} 2$ arrest $(4 \mathrm{~N}=17.5 \%)$; long transformation time of 11 months. Cytologically severe nuclear abnormalities. (b) Case 15: no hyperdiploid aneuploidy $(5 c E R=0)$. Little variation around normal $2 c$ value $(2 c D I=0.76)$ and low fraction of $G_{2}$ cells $(4 N=8.5 \%)$. Short transformation time of one month. Cytologically no nuclear abnormalities. 
be worth while knowing if computing the 5cER in granulopoietic and megakaryopoietic cells would result in a further increase of the sensitivity of DNA image cytometry.

Surprisingly, hypodiploidy, which was recorded separately, was of no diagnostic relevance. Hypoploidy was also present in pernicious anaemia, probably due to the defect of DNA synthesis in these cases. 5cER, which only recognises hyperdiploid but not hypodiploid aneuploidy, can therefore be regarded as the most adequate diagnostic DNA variable.

Our second algorithmic variable, $2 \mathrm{cDI}$, was of no discriminative value for the diagnosis of MDS because the values varied within the same range in MDS and in pernicious anaemia. Once the diagnosis of MDS is established, however, 2cDI might help define the prognosis. In our study the time span to development of ANL (transformation time) was positively correlated with $2 \mathrm{cDI}$. Low $2 \mathrm{cDI}$ values indicated imminent leukaemic transformation; high $2 \mathrm{cDI}$ values were associated with a longer stable course. For diagnostic purposes we chose only cases which were retrospectively verified as MDS by the later development of ANL. As patients with true MDS may succumb to infection or bleeding without manifestation of leukaemia our results, which indicate the prognostic relevance of $2 \mathrm{cDI}$, may be biased. The prognostic implication of this index therefore needs confirmation in a prospective study.

$2 \mathrm{cDI}$ was influenced by cell cycle variables. In pernicious anaemia the index was indirectly dependent on the fraction of $S$ cells $(2 n-4 n \%)$, reflecting a variable prolongation of the $S$ phase due to the defect of DNA synthesis. In MDS, however, 2cDI was positively correlated with the fraction of $G_{2}$ cells $(4 n \%)$ but not with the fraction of S cells, though both variables were increased. As has been shown earlier, ${ }^{13}$ an increase of the $\mathrm{G}_{2}$ fraction of erythropoietic cells is mainly found in the RA and AISA subtypes of MDS, and is due to a large amount of $\mathrm{G}_{2}$ arrested cells.

In conclusion, in patients with megaloblastic anaemia DNA image cytometry distinguishes MDS from secondary changes due to pernicious anaemia and also provides valuable prognostic information in MDS. The algorithm reported here may be of importance for clinical routine diagnosis.

This work was supported by grants from the Ministry of Higher Education and Research, Nordrhein Westfalen, Düsseldorf, West Germany. Dr Auffermann was a Research Associate at the departments of pathology of the Universities of Cologne and Aachen and is now a Research Fellow at the departments of Radiology, Technical University of Aachen (FRG) and University of California, San Francisco, California, USA.

\section{References}

1 Jacobs A. Myelodysplastic syndromes: pathogenesis, functional abnormalities, and clinical implications. J Clin Pathol 1985;38:1201-17.

2 Bennett JM, Catovsky D, Daniel MT, et al. Proposals for the classification of the myelodysplastic syndromes. Br J Haematol 1982;51:189-99.

3 Saarni MI, Linman JW. Preleukemia: the haematologic syndrome preceding acute leukemia. Am J Med 1973;55:38-48.

4 Schmalzl F, Konwalinka G, Michlmayr G, Abbrederedis K, Braunsteiner $H$. Detection of cytochemical and morphological anomalies in "preleukemia". Acta Haematol (Basel) 1978;59: 1-18.

5 Fohlmeister I, Fischer R, Schäfer HE. Preleukemic myelodysplastic syndromes (MDS): Pathogenetical considerations based on retrospective clinicomorphological sequential studies. Anticancer Res 1985;5:179-88.

6 Fohlmeister I, Fischer R, Mödder B, Rister M, Schäfer H-E. Aplastic anemia and the hypocellular myelodysplastic syndrome: histomorphological, diagnostic, and prognostic features. J Clin Pathol 1985;38:1218-24.

7 Prchal JT, Throckmorton DW, Carroll AJ, Fuson EW, Gams RA, Prchal JS. A common progenitor for human myeloid and lymphoid cells. Nature 1978;274:590-1.

8 Nowell PC. Cytogenetics of preleukemia. Cancer Genet Cytogenet 1982;5:265-78.

9 Abkowitz JL, Fialkow PJ, Niebruge DJ, Raskind WH, Adamson JW. Pancytopenia as a clonal disorder of a multipotent haemopoietic stem cell. J Clin Invest 1984;73:258-61.

10 Raskind WH, Tirumali N, Jacobson R, Singer J, Fialkow PJ. Evidence for a multistep pathogenesis of a myelodysplastic syndrome. Blood 1984;63:1318-23.

11 Maiolo AT, Foa P, Mozzana R, et al. Flow cytometric analysis of cellular DNA in human acute nonlymphatic leukemias and dysmyelopoietic syndromes. Cytometry 1982;2:265-7.

12 Pedersen-Bjergaard J, Vindeløv L, Philip P. Varying involvement of peripheral granulocytes in the clonal abnormality-7 in bone marrow cells in preleukemia secondary to treatment of other malignant tumours: cytogenetic results compared with results of flow cytometric DNA analysis and neutrophil chemotaxis. Blood 1982;60:172-9.

13 Montecucco C, Riccardi A, Traversi E, Giordano P, Mazzani G, Ascari E. Proliferative activity of bone marrow cells in primary dysmyelopoietic (preleukemic) syndromes. Cancer 1983;52: $1190-5$.

14 Peters SW, Clark RE, Hoy TG, Jacobs A. DNA content and cell cycle analysis of bone marrow cells in myelodysplastic syndromes (MDS). Br J Haematol 1986;62:239-45.

15 Walle AJ, Niedermayer W. Aneuploidy as marker of minimal residual disease in leukemia. Cancer Detect Prev 1985;8:303-15.

16 Böcking A, Adler CP, Common HH, Hilgarth M, Granzen B, Auffermann W. Algorithm for a DNA-cytophotometric diagnosis and grading of malignancy. Analyt Quant Cytol 1984;6: 1-8.

17 Böcking A, Auffermann W. Algorithm for DNA-cytophotometric diagnosis and grading of malignancy. Analyt Quant Cytol 1986;8:363.

18 Auffermann W, Urquardt $M$, Rübben $H$, Wohltmann D, Böcking A. DNA-grading of urothelial carcinoma of the urinary bladder. Anticancer Res 1986;6:27-32.

19 Böcking A, Schunk K, Auffermann W. Exfoliative-cytologic diagnosis of basal-cell carcinoma, with the use of DNA image cytometry as a diagnostic aid. Acta Cytol 1986;31:143-9.

20 Böcking A, Auffermann W, Vogel H, Schlöndorff G, Göbbels R. Diagnosis and grading of malignancy in squamous epithelial lesions of the larynx with DNA cytophotometry. Cancer 1985;56:1600-4.

21 Auffermann W, Böcking A. Early detection of precancerous lesions of the lung by rapid DNA-image cytometry. Analyt 
Quant Cytol 1985;7:218-27.

22 Böcking A, Hilgarth $\mathrm{M}$, Auffermann W, Hack-Werdier $\mathrm{CH}$, Fischer-Becker D, von Kalkreuth G. DNA-cytometric diagnosis of prospective malignancy in borderline lesions of the uterine cervix. Acta Cytol 1986;30:608-15.

23 Böcking A, Auffermann W, Jocham D, Contractor H, Wohltmann D. DNA-grading of malignancy and tumor regression in prostatic carcinoma under hormone therapy. Appl Pathol 1985;3:206-14.

24 Böcking A, Chatelain R, Auffermann W, et al. DNA-grading of malignant lymphomas. I. Prognostic significance, reproducibility and comparison with other classifications. Anticancer Res 1986;6:1205-16.

25 Böcking A, Chatelain R, Auffermann W, et al. DNA-grading of malignant lymphomas. II. Correlation with clinical parameters. Anticancer Res 1986;6:1217-24.

26 Auffermann W, Repges R, Böcking A. Rapid diagnostic DNAcytometry with an automatic microscope and a TV-image analysis system. Analyt Quant Cytol 1984;6:179-88.

27 Silvestrini R, Piazza R, Riccardi A, Rilke F. Correlation of cell kinetic findings with morphology of non-Hodgkin's malignant lymphomas. JNCI 1977;58:499-504.

28 Ricardi A, Martinotti A, Montecucco CM, Mayini G, Giordano P. Effect of vincristine on bone marrow cells of patients with multiple myeloma. A cytokinetic study. Virchows Arch (Cell Pathol) 1981;35:239-48.

29 Barlogie B. Abnormal cellular DNA content as a marker of neoplasia. Eur J Cancer Clin Oncol 1984;20:1123-5.

30 Hellriegel K-P. Chromosome findings in preleukemia. In: Schmalzl F, Hellriegel K-P, eds. Preleukemia. Berlin: Springer Verlag, 1979:68-75.

Reprint requests to: W Auffermann, Department of Radiology, University of California San Francisco, San Francisco, CA 94143, USA. 